\title{
FiLÓSOFO E OPERÁRIO: O SONETO "SPINOZA" DE Machado De Assis
}

\author{
Fernando Bonadia de Oliveira ${ }^{1}$ \\ Para Jucimara Tarricone
}

Resumo: Machado de Assis (1839-1908), um dos mais famosos escritores brasileiros, oferece um retrato de Bento de Espinosa em um soneto de 1880. Em seus versos, o poeta combina, do início ao fim, a imagem do pensador como operário (polidor de lentes) e como filósofo (criador de uma filosofia). Apesar de certa imprecisão nos traços estampados no retrato, o artigo pretende mostrar que o soneto pode, tanto quanto o poema "Spinoza", de Jorge Luis Borges, operar como um primeiro convite ao estudo do espinosismo. Embora nấo haja qualquer intenção de realizar uma exegese propriamente literária do poema, busca-se desvendar as singularidades da imagem machadiana de Espinosa, confrontando-a aos escritos do filósofo e aos dados disponíveis a respeito de sua vida.

Palavras-Chave: Espinosa. Machado de Assis. Soneto.

\section{INTRODUÇÁO}

A Revista Brasileira, em seu terceiro volume, de 15 de janeiro de 1880, publicou pela primeira vez, entre outros poemas assinados por Machado de Assis, um soneto intitulado "Spinoza".

\section{SPINOZA}

Gosto de ver-te, grave e solitário,

Sob o fumo de esquálida candeia,

Nas mãos a ferramenta de operário,

E na cabeça a coruscante ideia.

${ }^{1}$ Professor de Filosofia da Educaçáo e Filosofia da Educação Brasileira do Instituto de Educaçâo da Universidade Federal Rural do Rio de Janeiro (UFRRJ), Rio de Janeiro - Brasil. E-mail: fernandofilosofia@hotmail.com

http://dx.doi.org/10.1590/0101-3173.2018.v41n4.03.p31 
E enquanto o pensamento delineia

Uma filosofia, o páo diário

A tua máo a labutar granjeia

$\mathrm{E}$ achas na independência o teu salário.

Soem cá fora agitaçôes e lutas, Sibile o bafo aspérrimo do inverno,

Tu trabalhas, tu pensas, e executas

Sóbrio, tranquilo, desvelado e terno,

A lei comum, e morres, e transmutas

O suado labor no prêmio eterno.

(ASSIS, 2009, p. 242) ${ }^{2}$

Jorge Luís Borges, literato argentino, também compôs um soneto ao filósofo. Alvo de uma interessante perscrutação de Maria Luísa Ferreira, bem esquadrinhada em um brilhante artigo, o poema de Borges foi entâo interpretado como uma "entrada motivadora" na filosofia de Espinosa (FERREIRA, 2007 , p. 68). Conquanto admita que a função desenvolvida pela poesia não seja exatamente ensinar, a autora apresenta sua instigante leitura daquele soneto, esclarecendo suas imprecisóes históricas e lançando alguns de seus fragmentos a uma referência concreta na filosofia espinosana. Sem prejudicar a imaginação, a metáfora e a sugestão oferecida pelos versos, a professora Maria Luísa Ribeiro revela o "Espinosa de Borges" como um homem envolto em uma "aura de mistério", "personagem que oculta e disfarça", "temeroso do que afasta seu projeto de vida”. A autora destaca a representação poética de Espinosa, pouco verossímil, como judeu solitário e imperturbável, prenhe da mais elevada tranquilidade de alma (FERREIRA, 2007, p. 61).

O soneto de Machado destoa, em certos aspectos, do de Borges. Se o poeta argentino cria, em suas estrofes, um Espinosa de várias imagens (“judeu", "solitário", "livre do prazer sensual", "liberto da metáfora e do mito"), o brasileiro nos oferece uma única representação do autor da Ética: a combina-

\footnotetext{
2 Ainda que outras ediçôes da obra poética machadiana possam ser consultadas e lidas, optamos por esta versão do soneto por corresponder de forma mais fiel à versão final, publicada pelo autor ainda em vida. Depois de lançado na Revista Brasileira, esse soneto foi republicado com leve alteraçáo no livro Ocidentais (1901). Esse volume encerra a série de obras poéticas do escritor, composta por Crisálidas (1864), Falenas (1870) e Americanas (1875). Comumente, o título do poema aparece registrado "Espinoza" ou "Espinosa". Embora o nome do filósofo tenha sido grafado por nós, ao longo deste artigo, como "Espinosa", respeitaremos o título conforme sua redação original ("Spinoza”).
} 
ção entre a figura do operário e do filósofo. No entanto, assim como Borges, Machado também se desvia da reta compreensão da vida de Espinosa: descreve-o como solitário, impassível diante das manifestaçôes políticas e humanas, edificando, como que à parte disso, uma filosofia.

É digno de nota o fato de Machado ter deixado de lado os grandes chavốes que envolvem a representação comum do pensador de Amsterdá. No corpo do soneto, não há qualquer menção à origem judaica de Espinosa, à excomunhão da comunidade judaico-portuguesa de Amsterdá, ao seu propalado "ateísmo", ao seu conhecimento do cartesianismo, ou mesmo à sua tradicional imagem de revolucionário napolitano ao estilo de Masaniello. $\mathrm{O}$ poeta, ao pintar o filósofo, toma-o sempre na tensão entre o trabalhador e o pensador; mesmo em passagens do poema que sugerem as linhas gerais de seu pensamento, a atmosfera continua ligada às interfaces entre trabalho e intelecto. Interessa ainda observar que a figuração do "trabalhador Espinosa" não se explicita, nos versos do soneto, por meio do ofício específico que ele realizava, isto é, o polimento de lentes. Machado não nos mostra, como de costume, um polidor atento e zeloso com suas lentes, porém, um trabalhador assalariado que financia sua própria conservação e liberdade.

Ainda que Machado veicule certo preconceito comum sobre Espinosa, sua representaçáo pode servir, tal como o canto de Borges, para um primeiro convite ao espinosismo. Entretanto, aqui, não se trata tanto de pensar o soneto como forma de introdução ao pensamento do filósofo, como fez Ferreira com o escritor argentino, mas como um caminho para forjar uma imagem mais bem lapidada de Espinosa, seja a partir de breves conjecturas relativas à produção do poema (o momento de sua composição, publicação e republicação), seja à luz do problema central colocado nas últimas linhas da Ética: o sábio e sua felicidade, encarada não como "prêmio da virtude", mas como a própria virtude, o "prêmio eterno" daquele que se dedica, com a maior tranquilidade possível, ao conhecimento da verdade.

\section{A história do poema}

$\mathrm{Na}$ segunda metade de século XIX, Espinosa não era, como cem anos antes, um autor táo desconhecido ou tâo mal interpretado. Certamente, os estigmas impostos principalmente pelo Dicionário histórico-crítico de Bayle ainda estavam hegemonicamente estabelecidos, carregando estereótipos de Espinosa que foram sendo superados ao longo do século XX. O filósofo de 
Amsterdã já havia passado, a essa altura, pelo crivo mais rigoroso dos iluministas franceses (como Diderot e Voltaire, por exemplo) e por interpretaçóes mais autênticas de filósofos e intelectuais alemães, os quais de fato o estudaram, como Goethe (2005, p. 134-143), em seu "Estudo sobre Espinosa" (escrito a partir de sua leitura da Ética), de 1785, Hegel (1955, p. 280-310), em suas Liçôes de história da filosofia, de 1818, e até mesmo Schopenhauer (2003, p. 60-66), nos Fragmentos para a história da filosofia, publicado nos Parerga e paralipomena, em 1851.

Quando e em razão de qual circunstância teria Machado recebido a primeira notícia de Espinosa? Qual visão do espinosismo o teria afetado naquela cidade do Rio Janeiro ainda escravista, mas intimamente ligada às novidades europeias, por ser a grande cidade do Império brasileiro? Infelizmente, é impossível saber ao certo, de acordo com os dados até agora colhidos, quais seriam as respostas a tais perguntas. ${ }^{3}$ A resposta mais natural - que Espinosa chegou a Machado pela leitura de Schopenhauer - é bastante coerente. ${ }^{4} \mathrm{O}$ que se pode definir com mais certeza é apenas o período no qual Machado aprofundou seu conhecimento de Espinosa e arquitetou seu soneto.

$\mathrm{Na}$ lista de livros da biblioteca pessoal de Machado de Assis (JOBIM, 2000), constam dois volumes de Spinoza, provavelmente manuseados pelo escritor: I) a primeira série das Oeuvres completes, de G. B. Prat, que contém as biografias de Espinosa escritas por Lucas e Colerus, os Princípios da filosofia cartesiana, acrescidos dos Pensamentos metafísicos, traduzidos sob o título de

\footnotetext{
3 Para obter as respostas desejadas, seria necessário inventariar as edições e traduções de Espinosa disponíveis na época (e não somente as que Machado possuía, em sua biblioteca pessoal), verificar as citaçóes nos periódicos e em livros publicados no período. Mas este seria um trabalho de fôlego sobre a recepção de Espinosa no Brasil, não se fazendo necessário para fundamentar a interpretação proposta aqui para o poema.

${ }^{4}$ Tal hipótese foi bem fundamentada por Marilena Chaui, tendo em mente as "preferências filosóficas" de Machado de Assis, as quais desembocam naturalmente em Schopenhauer. Em seu parecer, Schopenhauer esquece que as biografias de Lucas e Colerus descrevem um "tipo moral seiscentista" e não um "indivíduo". Ele "vê Espinosa sob o prisma da subjetividade e da individualidade criados pelo Romantismo" e instaura uma perspectiva de leitura do pensamento espinosano que tende a desqualificar a obra do filósofo e simultaneamente exaltar o "caráter íntegro" da pessoa do filósofo (CHAUI, 1999, p. 7n, 27). Mostraremos que a leitura machadiana aponta em um sentido de exaltação da pessoa de Espinosa como trabalhador e pensador, sem a desqualificação da obra, seja a "obra" entendida como a lente polida, seja a filosofia formulada. Ao mesmo tempo, demonstraremos as finas ligaçōes entre o soneto e os termos das duas biografias (Lucas e Colerus), sem, evidentemente, conduzir a exposição à exaustão.
} 
Méditations métaphisiques (SPINOZA, 1873) e II) a segunda série das Oeuvres completes (SPINOZA, 1872), toda ocupada pelo Tratado teológico-político. ${ }^{5}$

Se levarmos em consideração que os dois volumes da tradução francesa preparada e anotada por Prat datam de 1872/1873, e que o poema aparece publicado pela primeira vez em 1880, é possível suspeitar que ele tenha sido pensado e composto nesse intervalo de tempo. Náo obstante, é impossível afirmar isso com segurança. Sabe-se, contudo, pelo conteúdo das duas peças espinosanas localizadas em seu acervo, que o escritor já poderia (à altura de 1880) conhecer o filósofo sob algumas perspectivas, entre elas, a partir daquilo que Lucas e Colerus comentaram de sua vida (nas biografias), sua leitura de Descartes (nos Princípios e nos Pensamentos metafísicos), sua interpretação da Escritura, bem como os fundamentos de sua doutrina política e defesa da liberdade de pensamento (presentes do Tratado teológico-político).

Nenhuma marca dos Princípios, dos Pensamentos metafísicos e do Tratado transparece nitidamente no soneto; todavia, o quadro criado por Machado para construir a figura de Espinosa parece envolver, como será visto mais adiante, as linhas gerais da descrição biográfica de Lucas e Colerus. Fora de dúvida está o fato de que Machado pode ter conhecido algo substancial da filosofia e da vida de Espinosa antes e durante a composição do soneto. Conforme pretendemos mostrar adiante, é ao menos lícito concluir que podemos interpretar o terceto final como uma incorporação conceitual e filosófica fiel ao espinosismo.

\section{As DUAS EDIÇÓES DO POEMA EM VIDA DO AUTOR}

Ao menos três edições de "Spinoza" foram preparadas, enquanto Machado ainda era vivo: a primeira, na Revista Brasileira (1880), a segunda, nas Poesias completas (1901), e a terceira, na segunda edição dessa obra (1902). ${ }^{6}$

\footnotetext{
5 Os dois livros foram catalogados dentro do item "Obras gerais". De acordo com o "catálogo atualizado da biblioteca de Machado de Assis", o livro foi adquirido na "Livraria acadêmica J. G. Azevedo" (JOBIM, 2000, p. 35, 149).

${ }^{6}$ Foi possível consultar dois exemplares das Poesias Completas (ediçấo de 1901), no setor de obras raras da Biblioteca Central César Lattes da Universidade Estadual de Campinas (BCCL/UNICAMP). O primeiro se acha na coleção "Oficina do Livro"; o segundo, na coleção "Aristides Cândido de Melo Souza". Um exemplar da edição de 1902, disponível na coleção "Primeiras Ediçōes", foi também consultado. Cotejando-se rapidamente os volumes de 1901 e 1902, percebeu-se que eles em nada diferem, a não ser no ano da publicação registrado na primeira página.
} 
Os vinte anos que separam a primeira edição das demais não são quaisquer vinte anos, mas as duas décadas em que Machado deixou de ser apenas o inteligente mulato autor de romances como Ressurreição (1872), A mão e a luva (1874), Helena (1876) e Iaiá Garcia (1878) para se tornar o consagrado criador dos clássicos Memórias póstumas de Brás Cubas (1881), Quincas Borba (1891) e Dom Casmurro (1899).

O soneto "Spinoza" foi publicado na Revista Brasileira junto a cinco outras poesias: "O desfecho", "Uma creatura", "A mosca azul", "No alto" e "Suave mari magno" (ASSIS, 1976, p. 48). Não há nada que, à primeira vista, evidencie um núcleo comum aos seis poemas, a não ser talvez o fato de todos eles carregarem um tom mais meditativo do que propriamente emotivo. O traço assinalado como característico das publicaçóes da Revista Brasileira parece valer para toda a poesia de Machado, que é tradicionalmente estimada como portadora de uma voz muito pouco emotiva e demasiadamente filosófica. Aproximemo-nos um pouco mais dessa interpretação tradicional da poesia de Machado.

Em uma carta redigida em 30 de outubro de 1899 ao seu editor Garnier, o escritor comunicou pela primeira vez o projeto de fazer publicar todas as suas poesias. A advertência do autor, constante na primeira edição, foi assinada no dia 22 de julho de 1900, o que leva a supor que, por essa data, já estivesse feita a seleção dos poemas que seriam incluídos no volume. $\mathrm{O}$ contrato para a publicação foi assinado no dia sete de agosto de 1900, sendo o livro impresso em Paris, com o ano de 1901 estampado na página inicial. Em abril ou maio de 1901, o livro chegou às livrarias e, táo logo foi localizado pelos leitores, já passou por uma sessão de críticas, algumas pesadíssimas. As análises retomadas abaixo foram todas publicadas entre os dias 20 e 27 de maio de 1901 (MACHADO, 2003, p. 235-258).

Múcio Teixeira escreveu que Machado, "depois de mais de quarenta [anos] empregados em teimosas lucubraçóes literárias, [...] apenas conseguiu encher 376 páginas de trabalhados versos”. Em sua concepção, "alguns [poemas são] de uma monotonia soporífera, todos os outros verdadeiramente intragáveis". Havia no autor das Poesias Completas "um bom prosador a amparar um medíocre poeta" que, embora soubesse versejar corretamente, bolando versos bem metrificados "como ensina o compêndio", não possuía propriamente poesia (p. 236): "além de velho e achacado", ele teria sido sempre, na opiniáo de Teixeira, "um platônico contemplativo e débil”. Em seguida, referindo-se a Machado de Assis como um burocrata (em função das ocupaçóes profissionais 
que o escritor assumiu, desde os tempos do Império até a então recém-nascida República), ele sentencia finalmente: "nasceu para a pacatez burocrática este versejador de meia-tigela.” (p. 241).

Medeiros e Albuquerque (cujo pseudônimo é J. dos Santos) e Sílvio Romero também criticaram a obra. O primeiro avaliou que, de Crisálidas a Ocidentais, Machado passou, como poeta, por um "retraimento crescente" da emoção; na última obra, em seu parecer, não haveria uma poesia sequer que se pudesse qualificar como "subjetiva" (p. 253). O segundo crítico, mais ácido, afirma que a leitura do conjunto de poesias de Machado daria prova "da pouca variedade de suas tintas, da pequena riqueza de seu vocabulário, da pouca nitidez de sua paisagem, dos parcos limites de sua imaginativa, do pouco ardor de sua emotividade, dos poucos recursos de seu estro." (p. 255). Julgando repetidas vezes o poeta como inferior ao prosador, declara enfim que "o sr. Machado de Assis é um dos nossos três maiores romancistas, um dos melhores prosadores; mas, como poeta, é de ordem secundária.” (p. 257).

José Veríssimo, na mesma semana em que Múcio Teixeira escreveu sobre as Poesias Completas, publicou sua resenha do livro. Mais ponderado em suas notas críticas e demonstrando profundo apreço pelo autor, Veríssimo compartilha o juízo hegemônico a respeito da poesia machadiana, como carente de uma expressão autêntica da emoção e como excessiva em seu tom hesitante de expressar o sentimento poético. No entanto, o crítico procura encontrar uma justificação para isso, no espírito e no temperamento do escritor, que estaria muito constrangido pela "doença do século, o seu ceticismo, o pessimismo, as complicaçóes e as dúvidas do seu pensamento.” E arremata: “a continência da sua sensibilidade, o jeito cético e pessimista de seu espírito [...] tiram [...] à sua poesia o que ela devia ter de emoção, de vida, de sentimento para nos tocar e comover." (p. 251-252). Veríssimo consegue explicitar em sua análise o que se podia encontrar de "novo" em Ocidentais, e não estava dado ainda nas obras poéticas anteriores (Crisálidas, Falenas e Americanas):

As Ocidentais não têm mais nada de americano, de particular ou local. Inspira-as e domina-as o pensamente geral e comum das gentes do Ocidente. E eu direi com pesar que há nelas ainda menos emoção que nas suas irmấs primeiras. O que nelas há de mais novo, e para dizer à moda, mais forte, são as poesias de pensamento, ou filosóficas. (p. 249).

Essa insistência no caráter mais racional e reflexivo das Poesias completas - o qual impediria o autor de obter, com versos, o mesmo sucesso que sempre 
logrou com a prosa - perpassa todas as críticas encontradas. Porém, nenhum crítico dá-se o trabalho de mencionar o poema sobre Espinosa. Os poemas mais discutidos de Ocidentais são "Círculo vicioso", "A mosca azul", "O desfecho", "Mundo interior", entre outros. Apesar disso, o traço "mais filosófico" da poesia machadiana também transparece com muita intensidade no "Spinoza", que será agora analisado.

\section{O SONETO}

"Spinoza" é o décimo terceiro poema de Ocidentais, mas o filósofo não é a única figura masculina a ser cantada no livro: além dele, são feitos versos a Artur de Oliveira, Antônio José, Gonçalves Crespo, José de Alencar, Luís de Camóes, José de Anchieta e Felício dos Santos. ${ }^{7}$ A elevada estima que Machado deveria ter por Espinosa para, afinal, colocá-lo entre grandes nomes da literatura universal e da língua portuguesa não é o único fato que desperta atenção, nessa lista de nomes. $\mathrm{O}$ antecessor de Espinosa na ordem de homenageados do livro é Antônio José da Silva (1705-1739), outro intelectual de origem judaica, dramaturgo, filho de "marranos", como eram chamados os judeus convertidos à força ao catolicismo. As comédias do "Judeu", como ele foi apelidado, causaram o riso em plateias portuguesas, mas tiveram um desfecho lúgubre, com sua morte na fogueira do Santo Ofício. Diferentemente do soneto "Spinoza", o curto poema dedicado ao grande teatrólogo faz menção à sua origem judaica, nos versos: "Tu, sangue de Efraim e Issacar/ Pois que já riste, chora.” (ASSIS, 2009, p. 242).

Kênia Pereira (2012), em interessante análise dos dois poemas, assegura que ambos trabalham paradoxos e contradiçóes. Ela declara: "Machado, ao homenagear os marranos Espinosa e Antônio José em seus devaneios líricos, tanto demonstrou compaixão para com as vidas trágicas destes dois escritores heréticos, como também profundo conhecimento de seus escritos ousados e polêmicos." (PEREIRA, 2012, p. 7).

A disposição dos dois cantos, um após o outro, revela a intenção do autor de destacar, em conjunto, os dois grandes judeus. Se, por um lado, a origem familiar dos homenageados e a exploraçáo de paradoxos os aproximam, de outro, o conteúdo de cada um dos paradoxos é, evidentemente, distinto. Em “Antônio José”, a grande contradição se nota entre o riso e o choro (ale-

${ }^{7}$ Não mencionamos, a seguir, os grandes nomes da literatura mundial que têm poemas traduzidos por Machado em Ocidentais, como Shakespeare, Edgar Allan Poe, La Fontaine e Dante. 
gria e tristeza); em "Spinoza", os contrários são expressos pela vida operária (prática) e a vida filosófica (teórica). Ora, conforme sustenta Novinski (1990), Machado de Assis observava com funda simpatia o caminho trilhado pelos judeus, ao longo da história, e, portanto, não há dúvida de que seu esforço por poetar o filósofo Espinosa pode ter-se originado dessa simpatia. Por outro lado, a diferença parece acentuar, no caso do judeu-filósofo, uma insistência em um ponto profundamente filosófico e político.

É precisamente nesse sentido que argumentaremos a seguir, estabelecendo uma leitura verso a verso do soneto.

\section{"Gosto de ver-te... Sob o fumo de esquálida candeia"}

A despeito do que poderia pensar parte dos críticos, o começo do poema é profundamente subjetivo: "Gosto". Ao eu-lírico apraz "ver". Trata-se de uma visão imaginária, isto é, da visão de uma imagem que causa alegria, que dá gosto, como uma pintura em um quadro que se aprecia. Nessa impressão, Espinosa aparece fechado entre quatro paredes, protegido do "bafo aspérrimo do inverno" que sibila "cá fora". Iluminado por uma singela candeia que queima e aclara o espaço, Espinosa pensa uma filosofia, trabalha como um operário. A luz da candeia, por ser esquálida e, portanto, magra, nos permite vislumbrar algo que se aproxima das luzes e sombras das telas de Rembrandt (1606-1669), outro holandês, contemporâneo de Espinosa, considerado um dos maiores nomes da arte europeia. A luminosidade oferecida pelo poema não se limita àquela do espaço em que se acha o filósofo, mas se estende também à de sua mente, ativa na composição de ideias. $\mathrm{O}$ adjetivo empregado pelo poeta para qualificar a ideia espinosana é "coruscante", algo que brilha. Desse modo, tanto no espaço que circunda o filósofo trabalhador quanto no interior de sua mente impera a luz, o que compóe, assim, uma imagem lúcida.

"Nas mãos... na cabeça..." [...] "O pensamento... a [...] mão..."

O núcleo da imagem, a saber, o filósofo, em seu aposento, trabalhando e pensando sob a fumaça da candeia esquálida, desdobra-se em uma simultaneidade de açóes que compóem os versos 3 a 7 . Há uma simultaneidade 
levemente sugerida pelo "e" do quarto verso, contudo, explícita no quinto, pelo "enquanto". A ferramenta nas mãos, ou seja, o instrumento do trabalho do operário na produção de sua mercadoria é acompanhado do instrumento operado pelo filósofo em sua cabeça: a ideia, coruscante, animada, em férvida produtividade.

Nos versos 5, 6 e 7, "as máos", que tiveram a prioridade na estrofe anterior (onde se lê "nas mãos... e na cabeça..."), são então antecedidas pelo "pensamento": "enquanto o pensamento", em primeiro lugar, "delineia uma filosofia", "a mão granjeia", em um segundo momento, "o páo diário". ${ }^{8}$ Essa inversão entre o aspecto prático e o teórico, na passagem da primeira à segunda estrofe, balanceia a dupla expressão do filósofo no poema como operário e pensador: nem a cabeça tem prioridade sobre a máo, nem o oposto. Ambas atuam juntas, cada uma com seu instrumento: a ferramenta que prepara a lente e a ideia que esboça uma filosofia.

A filosofia, como se nota, é "delineada". O uso do verbo "delinear" (no verso 5) confere ao seu objeto (a filosofia) uma sensação de ofício em processo e em construção: enquanto trabalha, o pensamento também produz. Não está Espinosa, nessa bela visão, sobre os papéis empunhando uma pena, onde rabisca alguma sentença. Ele está ganhando seu pão diário e sendo afetado pelos pensamentos que, em outra hora, transformará em texto. É, então, a figura do operário que permanece em todo o poema, porém, um operário que filosofa, e não um filósofo simplesmente a filosofar. O "Espinosa operário" desenhado pelo poeta não é alguém que trabalha de forma incessante para enriquecer. $\mathrm{O}$ que ele ganha em sua labuta diária com seu salário não é a riqueza, mas a independência, isto é, a liberdade.

Machado pode ter tido informaçôes sobre essa vida modesta de Espinosa pelas biografias, presentes em sua biblioteca pessoal. A vida de Espinosa, de Lucas, noticia a famosa situação na qual Espinosa demonstra a seu amigo, Simon de Vries, todo o seu desapego à riqueza:

Um de seus amigos íntimos [Simon de Vries], um homem em boa situação financeira, queria dar-lhe [a Espinosa] de presente dois mil florins, para que pudesse viver mais comodamente. Ele recusa com sua polidez habitual,

\footnotetext{
${ }^{8}$ Múcio Teixeira anotou, em sua áspera crítica às Poesias Completas, que Machado, ao construir "versos soltos" (como aqueles dispostos no soneto aqui em estudo), se esquecia frequentemente de que esse tipo de técnica "não pode ter palavras esdrúxulas no final". O verso 6 (aquele que diz: "Uma filosofia, o pão diário") é colocado por ele como um dos exemplos dessa falha do escritor, em Ocidentais (MACHADO, 1976, p. 240).
} 
dizendo que não os necessitava. Com efeito, era tão moderado e sóbrio que mesmo com bem poucos bens, não lhe faltava nada. [...] [Espinosa] não gastava seis soldos por dia, fazendo a média, e não bebia mais que uma pinta de vinho por mês. (LUCAS, [20--?], \$24).

A recusa dos florins de Simon de Vries (que continuaria, tempo depois, tentando auxiliar o filósofo, financeiramente) mostra que Espinosa, como escreveu Colerus ([20--?], \$27), "não tinha nenhum apego ao dinheiro [...] e se contentava em ter, sem se preocupar com o futuro, o que lhe era necessário para sua alimentação e para sua subsistência."

Esse traço de desapego aos bens materiais pode ter atraído a atenção de Machado, tanto por se tratar de uma virtude rara nos filósofos da tradição escolástica, conforme chega a afirmar o próprio Lucas ([20--?], \$24), quanto porque o "salário" não era, para Espinosa, somente o pagamento pela venda de sua força de trabalho, mas, acima de tudo, a base da independência que lhe permitiria escrever sem qualquer forma de tutela e, portanto, sem ter ninguém a quem necessariamente agradar com seus escritos.

A independência alcançada em troca da labuta é a própria liberdade, afirmação da potência; é ela a causa da felicidade como "prêmio eterno", pois não corresponde, como veremos, à liberdade do solitário, mas à liberdade daquele que vive na cidade, entre seus concidadãos. Como se acha nas palavras de Espinosa: "O homem que é conduzido pela razão é mais livre na cidade, onde vive pelo decreto comum, do que na solidão, onde obedece apenas a si mesmo." (Ética IV, prop. 73).

\section{"Soem cá fora agitaçôes e lutas"}

Os tercetos que encerram o poema foram citados, certa vez, por Olavo Bilac, em discurso sobre Machado de Assis. Ele recorre a esse trecho de "Spinoza” para elaborar uma imagem do próprio criador da Academia Brasileira de Letras:

Um dia, descrevendo a austera figura de Spinoza, em um soneto de rara beleza, Machado de Assis mostrou-nos o filósofo, grave e solitário, no seu retiro de lida e pensamento, apartado das vấs ambiçóes e das cobiças grosseiras, cativo apenas do mundo interior das suas ideias [...]. Inspirou e ditou estes versos uma afinidade real entre dois espíritos de eleição. Sem 
o temperamento combativo do sombrio Spinoza, o nosso grande escritor teve a mesma dignidade de vida, a mesma abnegação modesta, a mesma escravização ao domínio exclusivo das ideias - e o mesmo gosto da solidão, que em certos homens não é timidez nem orgulho, mas somente a tristeza de quem se reconhece diverso do comum das gentes, e fadado a viver, se não ignorado, ao menos mal entendido dos seus contemporâneos. (BILAC, [20--?], p. 363).

Embora não tenham o objetivo de analisar os tercetos, mas apenas caracterizar, a partir deles, o próprio Machado, as palavras de Bilac reforçam a velha e conhecida imagem de Espinosa: seu isolamento ("apartado das vãs ambiçóes e das cobiças grosseiras") e seu fechamento em si mesmo ("cativo apenas do mundo interior das suas ideias"). Ainda que retire da imagem do escritor brasileiro "o temperamento combativo do sombrio Spinoza", atribui aos dois a "dignidade de vida", a "abnegação modesta”, a "escravização ao domínio exclusivo das ideias" e o "gosto da solidáo".

A descrição de Espinosa como um sujeito isolado e fechado em si mesmo não é, porém, uma realidade. Como lembra Ferreira, referindo-se ao soneto de Borges, "a ideia do isolamento de Espinosa é outro mito que se cria, mas que não corresponde à verdade, pois nem antes nem depois de sua excomunhão, levou a vida de segregado ou eremita." (FERREIRA, 2007, p. 63). Para a autora, a prova de que Espinosa não foi um homem solitário é seu sistemático intercâmbio epistolar e a grande lista de amigos que possuía; ademais, o convite que recebeu para ensinar filosofia em Heidelberg (Cartas 47 e 48) mostra como ele não estava desamparado e travava contato com figuras importantes.

De fato, várias "agitaçóes e lutas" percorreram a vida de Espinosa. Entre as agitaçôes, podemos mencionar as mortes que assolaram sua infância e juventude (da mãe, da madrasta, do pai e de irmãos), a peste que arrasou seu tempo e espaço, as diversas mudanças de cidade (de Amsterdã para Rijnsburg; dali para Voorburg e, finalmente, para Haia), as ameaças e perseguições (de judeus fanáticos a teólogos e autoridades ensandecidas com a publicação do Tratado teológico-político), as paixóes que certamente permearam sua existência e a administração de seus problemas pulmonares, os quais foram se intensificando até a morte. Entre as lutas, se as compreendermos como lutas propriamente políticas, basta-nos recordar os conflitos internos na comunidade judaico-portuguesa, onde disputavam diferentes leituras e interpretações dos 
livros sagrados, a Guerra Anglo-Holandesa, de 1665 a 1667, e finalmente a invasão da França, deflagrando a Guerra da Holanda, entre 1672 e 1673.

Todavia, em nenhuma dessas agitaçôes Espinosa deserdou ou correu para casa, a esconder-se entre os livros ou mesmo por trás da lida do trabalho. $\mathrm{Na}$ verdade, o filósofo tomou partido das agitaçôes; ele viu suas ideias divulgadas entre os judeus (o que acabou rendendo sua excomunhão), indignou-se contra o linchamento público dos irmãos De Witt (querendo, inclusive, ir ao encontro da multidão para censurá-la, loucura que foi impedida pela contenção dos amigos). Conta-se que atuou em missão diplomática para tentar interceder, junto aos invasores franceses, na Guerra da Holanda. Assim, se as "lutas e agitaçôes" soaram à porta do quarto de Espinosa, ele não esteve apartado delas, mas nelas interveio como conseguiu, de acordo com sua posição e suas possibilidades.

Desse modo, não se conforma à verdadeira representação de Espinosa o afeto de "tristeza" de alguém que "se reconhece diverso do comum das gentes". Ao contrário, vivendo de seu trabalho e tendo tempo para cultivar suas ideias, o filósofo executou a "lei comum" de toda a gente que trabalha e vive à custa do esforço da venda de sua força de trabalho. Diferentemente do que Bilac interpretou no poema, Espinosa também não esteve jamais "fadado a viver, se não ignorado, mal entendido dos seus contemporâneos."

Espinosa não foi, enfim, um homem solitário. Conforme sua filosofia ditava, ele evitava os favores dos ignorantes ${ }^{9}$, mas nunca a presença e a lealdade dos amigos verdadeiros, mesmo quando deles discordava, como foi o caso de Oldenburg, que lhe escreveu desde 1661 e com quem manteve a amizade intacta até praticamente o fim de sua vida. ${ }^{10}$ Além disso, Espinosa recebia visitas

\footnotetext{
9 Cf. Ética IV, prop. 70: "O homem livre que vive entre ignorantes se empenha o quanto pode em evitar os benefícios dados por eles."

${ }^{10}$ Uma carta de Espinosa a Oldenburg, a propósito, parece contribuir para a perspectiva de Machado relativa à impassibilidade de Espinosa diante de "agitaçóes e lutas". Trata-se da Carta 30, na qual Espinosa opina sobre uma etapa da guerra da Inglaterra em que ingleses e holandeses se deram uma trégua. Uma situação patética, digna de riso, segundo Espinosa. Porém, o filósofo ressalva: "a mim essas perturbaçōes [da guerra] não me incitam nem a rir nem a chorar, mas a filosofar e a observar melhor a natureza humana. Que aqueles que querem morram por seu bem, contanto que a mim seja permitido viver para a verdade." (SPINOZA, 1988, p. 230-231). Longe de significar impassibilidade ante o contexto político, a decisão espinosana por filosofar e observar a natureza humana tem em vista "buscar conhecer", ser afetado pelo "mais potente dos afetos". A fixidez do ânimo, a qual oferece a impressão de um homem impassível e tranquilo, não é fruto de um isolamento ou solidão, mas está ligada - como será visto, a seguir - ao conhecimento de si, das coisas singulares e de Deus. Por conseguinte, a ação de filosofar e observar se liga (de forma nada impassível) a um profundo sentimento de união com
} 
frequentes de representantes da intelectualidade da época, como, por exemplo, o filósofo Leibniz.

A serenidade de Espinosa, em meio a algumas das agitaçóes e lutas pelas quais passou, não significou estar à parte delas. Para Espinosa, o sábio não é, propriamente, aquele que não está exposto aos abalos do mundo, mas o que permanece constante, apesar deles e na medida do possível. Náo é outro o assunto que encerra a Ética:

O ignorante, além de ser agitado pelas causas externas de muitas maneiras, e de nunca possuir o verdadeiro contentamento do ânimo, vive quase inconsciente de si, de Deus e das coisas; e logo que deixa de padecer, simultaneamente deixa também de ser. Por outro lado, o sábio, enquanto considerado como tal, dificilmente tem o ânimo comovido; mas, cônscio de si, de Deus e das coisas por alguma necessidade eterna, nunca deixa de ser, e sempre possui o verdadeiro contentamento do ânimo. (Ética V, prop. 42, escólio).

Espinosa reconhece que é próprio do ignorante ser agitado por causas externas e ver dar-se em si mesmo aquilo de que é somente causa inadequada ou parcial. ${ }^{11} \mathrm{O}$ sábio não deixa de ser, porque é movido por uma "necessidade eterna"; ele vive segundo a disposiçáo interna de seu corpo e de sua mente, onde encontra o "verdadeiro contentamento do ânimo".

"Tu trabalhas, tu pensas, e executas... A lei comum"

O verso 11 do soneto ("Tu trabalhas, tu pensas, e executas") é o único que, segundo a apuração da Comissão Machado de Assis, foi alterado pelo autor entre a primeira publicação (na Revista Brasileira) e a edição posterior das Ocidentais. A redação inicial era: "Tu trabalhas, tu pensas; e executas," com ponto e vírgula no meio do verso e com vírgula no final. De acordo com as observações da Comissão, "pelo contexto, a versão da Revista Brasileira melhor exprime o contraste entre pensamento e ação" (ASSIS, 1976, p. 79). Sem dúvida, a formulação de 1880 (com o ponto e vírgula) marca de forma mais

as demais coisas da Natureza, como se nota, sobretudo, nos termos do Tratado da emenda do intelecto (ESPINOSA, 2015a, \$13).

${ }^{11}$ Cf. Ética III, prop. 59, escólio: abandonados à ordem comum da natureza, somos agitados por causas externas, "como ondas do mar agitadas por ventos contrários". 
expressiva a dualidade entre pensar e trabalhar, dualidade que se liga, no verso 13, a "lei comum". No entanto, mesmo com as correçóes da edição de 1901, "executar" aparece como corolário inevitável da combinação entre pensar e trabalhar.

A lei comum é, certamente, a lei que rege todos os infinitos modos da natureza, tanto os humanos quanto os não humanos. Ela é "comum", na medida em que se encontra na parte e no todo, nos modos e na substância (Deus). Ela é, a um só tempo, o que Espinosa chama "ordem comum da natureza" e sua "ordem necessária". Nos sábios, a lei comum é executada conforme a ordem necessária das coisas dadas em Deus e, assim, o ato de executá-las produz afetos racionais sempre relacionados a coisas eternas; nos ignorantes, a lei comum náo é executada, mas cumprida segundo a ordem comum, a qual, sob o registro da imaginação, deixa-se afetar pela duração das coisas, que deixam de ser. Ela é cumprida, porque é obedecida passivamente. Quando executada, a lei comum produz, ativamente, o "prêmio eterno", o constante e progressivo "tomar parte" da natureza. O ignorante imagina, o sábio entende, e sua capacidade de imaginar, pelo primeiro gênero de conhecimento, é muito menor em comparação à sua potência de conhecer pelo intelecto, pelas "noçóes comuns" e pela "ciência intuitiva", o segundo e o terceiro gênero, que, finalmente, realiza-se no "amor a Deus". O ignorante e o sábio sabem que vão morrer e sabem que são eternos. "Se atentarmos à opinião comum dos homens", escreve Espinosa, "veremos que eles certamente são cônscios da eternidade da sua Mente, mas a confundem com a duração e a atribuem à imaginação ou à memória, que eles acreditam permanecer após a morte." (Ética V, prop. 34, escólio).

Nessa perspectiva, ambos conhecem o mesmo, porém, por gêneros diferentes de conhecimento. Ligado aos afetos que se originam da imaginação, seguindo a ordem comum da natureza, o homem comum (communi vulgi) é submetido/induzido ao medo mais atroz e à esperança mais vã:

[Os homens comuns] creem que a Piedade, a Religião e absolutamente tudo que se refere à Fortaleza do ânimo são um ônus de que eles esperam livrar-se após a morte, recebendo a recompensa de sua servidáo, a saber, da Piedade e da Religiáo. E não só por esta esperança, mas também e principalmente pelo medo de serem punidos com terríveis suplícios após a morte, é que eles são induzidos, tanto quanto o suporta sua fragilidade e seu ânimo impotente, a viver segundo a prescrição da lei divina. (Ética V, prop. 41, escólio). 
Tanto essa esperança quanto esse medo "induzem" o homem a viver segundo a ordem comum da natureza, na qual ele se apega àquelas coisas que deixam de ser. O homem que conhece, por sua vez, é conduzido pela razão, não pelo afeto que é paixão: "Quanto mais a Mente intelige as coisas pelo segundo e pelo terceiro gênero de conhecimento, tanto menos padece dos afetos que são maus, e menos teme a morte." (Ética V, prop. 38).

O Espinosa de Machado de Assis, trabalhando e pensando conforme o segundo e o terceiro gênero de conhecimento, medita sobre a vida e desfruta do afeto mais potente: aquele que nasce do conhecimento das propriedades comuns das coisas, propriedades em relação às quais não pode ser dado nada que as faça deixar de existir ("que exclua a existência presente delas"):

Tal afeto permanece sempre o mesmo e, consequentemente [...], os afetos que lhe são contrários e que não são fomentados pelas respectivas causas externas deverão adaptar-se mais e mais a ele, até que não lhe sejam mais contrários, e nesta medida o afeto originado da razão é mais potente. (Ética $\mathrm{V}$, prop. 7 , demonstração).

Dentre os afetos originados da razão, o maior é o conhecimento da substância (Deus) e Espinosa o denomina "amor intelectual a Deus". As proposiçôes 28 e 36 da Ética IV ${ }^{12}$ permitem a demonstração, na Ética V, do "amor a Deus" como o sumo bem, comum a todos, o qual nos faz desejar que todos gozem dele. ${ }^{13}$ É nesse sentido que a lei que Espinosa trabalha, pensa e executa, é comum. Todos podem trabalhá-la e pensá-la, mas aquele que é guiado pelo exercício constante da "coruscante ideia" adequada, que se realiza, com labor diário (de operário e filósofo), no conhecimento cada vez maior das propriedades comuns e na experiência cotidiana do amor a Deus, este está mais próximo do sábio: "cônscio de si, de Deus e das coisas por alguma necessidade eterna, nunca deixa de ser, e sempre possui o verdadeiro contentamento do ânimo." (Ética V, prop. 42, escólio).

“... e morres, e transmutas" "O suado labor no prêmio eterno"

\footnotetext{
${ }^{12}$ Ética IV, prop. 28: "O sumo bem da Mente é o conhecimento de Deus e a suma virtude da Mente é conhecer Deus." Ética IV, prop. 36: "O sumo bem daqueles que seguem a virtude é comum a todos, e todos podem igualmente gozar dele."

${ }^{13}$ Ética V, prop. 20, demonstração: "Este Amor a Deus é o sumo bem que podemos apetecer pelo ditame da razão (pela prop. 28 da parte IV), é comum a todos os homens (pela prop. 36 da parte IV) e desejamos que todos gozem dele."
} 
O problema morte ou, como bem denomina Jailma Souto da Silva, "o enigma da morte" perpassa a obra de Machado de Assis, sobretudo os textos romanescos da segunda fase: Memórias Póstumas de Brás Cubas, Quincas Borba, Dom Casmurro, Esaú e Jacó e Memorial de Aires (2006, p. 15). Ao contrário, a filosofia de Espinosa despreza o tema da morte; para ela, como mostramos, o sábio filosofa a vida, não a morte. Bem compreensível seria se o poeta anotasse: “... e vives, e transmutas"; porém, o emprego de "morrer", antecedendo "transmutar", remete certamente a um "após a morte" - e a morte em questão é a morte singular de Espinosa.

As palavras de Lucas a respeito da morte de Espinosa, guardadas na biblioteca de Machado, são as seguintes:

A sobriedade, a paciência e a veracidade não eram mais do que suas virtudes menores. Ele teve a felicidade de morrer no cume de sua glória, sem a ter maculado com nenhuma mancha, deixando ao mundo dos sábios e doutos o desgosto de verem-se privados de uma luz que não lhes era menos útil do que a luz do sol. [...] Somos nós, os que ficamos, que estamos lamentando; são todos aqueles que seus escritos tenham retificado, e a quem sua presença era ainda um grande socorro no caminho da verdade. Mas já que não se pode evitar a sorte de tudo o que vive, procuraremos marchar sobre suas pegadas, ou ao menos reverenciá-lo com nossa admiração e louvor, se não podemos imitá-lo. É o que eu aconselho às almas sólidas, assim como seguir suas máximas e suas luzes, de tal forma que as tenham sempre ante os olhos e lhes sirvam de regras a suas açôes. O que nós amamos e veneramos nos grandes homens está sempre vivo e viverá por todos os séculos. [...] Baruch de Spinoza viverá na recordação dos verdadeiros sábios e em seus escritos, que são o templo da imortalidade. (LUCAS, [200--?], $\$ \$ 38-40)$.

Espinosa teve uma vida feliz, porque, durante o tempo em que viveu, cultivou as coisas eternas, trabalhando e pensando, executando a lei comum como um sábio, isto é, produzindo o conhecimento de Deus, de si mesmo e das coisas, legando ao mundo, como produto de sua labuta, as obras que eternizam uma filosofia delineada pelo pensamento e pela prática. Ainda mais exato é dizer que Espinosa fez de sua morte a transmutação de seu trabalho em "bem eterno". Seu labor foi suado no corpo, suado pelos longos anos de pensamento e preparaçấo da Ética; suado, enfim, pela dificuldade do caminho que apresenta a felicidade, tomada não como "prêmio da virtude", mas como a própria virtude em ato, o "prêmio eterno". 
Se agora parece árduo o caminho que eu mostrei conduzir a isso, contudo ele pode ser descoberto. E evidentemente deve ser árduo aquilo que táo raramente é encontrado. Com efeito, se a salvação estivesse à disposiçáo e pudesse ser encontrada sem grande labor, como explicar que seja negligenciada por quase todos? Mas tudo o que é preclaro é tão difícil quanto raro. (Ética V, prop. 42, escólio).

"Sem grande labor" não se alcança a salvação, escreve Espinosa. O "suado labor", por sua vez, transmuta-se em prêmio eterno, o prêmio de poder passar a vida a produzir ideias adequadas e a polir as lentes da filosofia, que tudo tornam preclaro.

\section{ESPINOSA EM ADJETIVOS}

Os adjetivos que Machado emprega para caracterizar Espinosa são "grave e solitário" (verso 1), "sóbrio, tranquilo, desvelado e terno" (verso 12).

"Solitário", como já foi explicado aqui, Espinosa realmente não foi. Se foi "grave" 14 , não se pode ter certeza: talvez, pela descrição das biografias (tanto de Lucas, quanto de Colerus), pode-se imaginar um Espinosa de compleição frágil, aspecto abatido e fatigado pela doença que o acompanhou por longo tempo. Entretanto, Renan, em seu discurso em Haia, no dia dos duzentos anos de morte de Espinosa, pinta-nos outro Espinosa, mais vívido e leve, sem marcas tão fortes de gravidade (RENAN, [1936], p. 40-41).

A "sobriedade"15 de Espinosa, notada desde Lucas, em sua descrição da morte do filósofo, foi, indubitavelmente, uma qualidade necessária para o filósofo. "Spinoza era de uma constituição muito débil, doentio, magro e atacado de tuberculose desde mais de vinte anos; a qual o obrigava a viver em regime e a ser extremamente sóbrio em seu beber e seu comer." (COLERUS, [20--?], \$64).

Espinosa também procurou sempre a "vida tranquila", mas sem se esconder em sua casa, solitário e alheio ao mundo. Ao declinar do convite de Ludovicus Fabritius para se tornar professor em Heidelberg (Carta 48), Espinosa apresenta suas razóes e assegura, finalmente, que foi sempre em nome

\footnotetext{
${ }^{14}$ Segundo o Dicionário Houaiss, o termo "grave", quando se diz da fisionomia humana, refere-se a uma figura sisuda, circunspeta, recatada.

15 Entende-se aqui a "sobriedade" conforme sua primeira significação, no Dicionário Houaiss: "moderação no comer e no beber".
} 
da tranquilidade de sua alma que nunca desejou ministrar liçóes públicas, preferindo viver com seu ofício de polidor de lentes (ESPINOSA, 2008, p. 114), de modo a poder se dedicar atentamente à produçáo de sua filosofia, seu "prêmio eterno".

O "desvelo" de Espinosa, se entendido como empenho diligente na produção de algo, com cuidado e carinho extremo, ${ }^{16}$ foram notáveis; aliás, seu próprio lema já anunciava: "Caute!" O mesmo se pode dizer de "terno" e da "ternura espinosana”. Contrariamente ao que a tradição repetidas vezes quis cultuar, Espinosa não foi sombrio, demoníaco, combativo, causador de cismas. Através das páginas da Ética, descobrimos a importância da generosidade e, pelos caminhos de sua biografia, o seu ato de generosidade maior: deixar ao mundo a obra que revela o conhecimento e os meios para se atingir a felicidade.

Não podemos deixar de sublinhar, a título de encerramento, a profunda convicção de que, como leitores filósofos, conseguimos ver no soneto mais do que um mero retrato subjetivo de Espinosa. Desenha-se ali uma imagem de sua filosofia que consiste no esforço pela "produção de totalidade" ${ }^{17}$ e pelo alcance do ponto de vista da eternidade. A morte precoce e trágica, frequente nas representaçóes convencionais do fatídico 21 fevereiro de 1677, não transparece nas últimas pinceladas desse belo retrato: o trecho final do soneto, longe disso, enuncia: "e morres e transmutas...", expressando talvez a "difícil e rara" conversão do "suado labor" do operário e do filósofo no prêmio de todos os seus leitores.

OLIVEIRA, F. B. Philosopher and craftsman: the sonnet "Spinoza" by Machado de Assis. Trans/form/ação, Marília, v. 41, n. 4, p. 31-52, Out./Dez., 2018.

\footnotetext{
${ }^{16}$ São significaçôes de "desvelo" e "desvelar(-se)" do Dicionário Houaiss.

${ }^{17} \mathrm{O}$ sentido da filosofia espinosana como "produção de totalidade" (expressão colhida do Breve Tratado) foi explorado de forma mais detalhada na tese Coerência e comunidade em Espinosa (OLIVEIRA, 2015, p. 205-255).
} 
ABSTRACT: Machado de Assis (1839-1908), one of the most well-known Brazilian writers, offers a portrait of Baruch Spinoza in a sonnet of 1880. In its verses, the poet combines the image of the thinker as a craftsman (polisher of lenses) and as a philosopher (creator of a philosophy). This article intends to show that despite the inaccuracy in the sonnet's portrayal of certain aspects of its subject, it can nevertheless, just like the poem "Spinoza" written by Jorge Luis Borges, act as a first call to the study of Spinozism. Without intending to perform a proper literary exegesis of the poem, the article seeks to unveil the singularities of Machado's image of Spinoza, confronting it with the philosopher's works and biography.

KEYwOrDs: Spinoza. Machado de Assis. Sonnet.

\section{REFERÊNCIAS}

ASSIS, M. Poesias. Rio de Janeiro: Garnier, 1901. Poesias. Rio de Janeiro: Garnier, 1902.

- Poesias completas: Crisálidas, Falenas, Americanas, Ocidentais. Texto estabelecido pela Comissão Machado de Assis. Rio de Janeiro: Civilização Brasileira; Brasília: INL, 1976.

Edusp, 2009.

A poesia completa de Machado de Assis. Organização R. Reis. São Paulo: Nankin;

BILAC, O. Discurso de Olavo Bilac. In: Guardados na memória. Rio de Janeiro: ABL, [20--?]. Disponível em: <http://www.machadodeassis.org.br/>. Acesso em: 14 jul. 2015.

CHAUI, M. Nervura do real. São Paulo: Companhia das Letras, 1999.

COLERUS, J. Vida de Spinoza. Tradução de E. Fragoso. [20--?]. Disponível em: $<$ http://benedictusdespinoza.pro.br/biografias-de-spinoza-colerus.html>. Acesso em: 13 maio 2016.

ESPINOSA, B. Tratado teológico-politico. Tradução de D. Aurélio. São Paulo: Martins Fontes, 2003.

. Carta 48. Tradução de F. Oliveira. Trilhas Filosóficas, Caicó-RN, n. 1, p. 113114, dez. 2008.

. Tratado político. Tradução de D. Aurélio. São Paulo: Martins Fontes, 2009.

. Tratado da emenda do intelecto. Tradução de C. Rezende. Campinas-SP: Editora da Unicamp, 2015a.

. Ética. Tradução de M. Chaui et al. São Paulo: Edusp, 2015b.

FERREIRA, M. L. Espinosa a partir de um poema. Revista Conatus, Fortaleza, CE, v. 1, n. 2, p. 61-68, dez. 2007. 
GOETHE, J. W. Estudo sobre Espinosa. Tradução de G. Leitáo. Cadernos Espinosanos, São Paulo, n. 13, p. 134-143, 2005.

HEGEL, G. Lecciones sobre la historia de la filosofía. Tradução de W. Rogers. Mexico-DF: Fondo de Cultura Económica, 1955.

HOUAISS, A. Dicionário da língua portuguesa. Rio de Janeiro: Objetiva, 2009.

JOBIM, J. L. (Org.). A biblioteca de Machado de Assis. Rio de Janeiro: Topbooks; ABL, 2000.

LUCAS, J. M. A vida e o espirito do senhor Benoit de Spinosa. [20--?]. Tradução de E. Fragoso. Disponível em: <http://benedictusdespinoza.pro.br/biografias-de-spinoza-lucas. html>. Acesso em: 13 maio 2016.

MACHADO, U. Machado de Assis: roteiro da consagração. Rio de Janeiro: EdUerj, 2003.

NOVINSKY, A. O olhar judaico de Machado de Assis. Rio de Janeiro: Expressão e Cultura, 1990.

PEREIRA, K. Dois marranos e um bruxo: Antonio José e Baruch Espinosa na poesia de Machado de Assis. Arquivo Maaravi: Revista Digital de Estudos Judaicos da UFMG, v. 6, n. 11, out. 2012. Disponível em: <http://www.periodicos.letras.ufmg.br/index.php/ maaravi/article/view/3072/3026>. Acesso em: 16 maio 2016.

RENAN. Spinoza. Tradução de J. Perez. São Paulo: Cultura, [1936].

SCHOPENHAUER, A. Fragmentos para a história da filosofia. Tradução de M. L. Cacciola. São Paulo: Iluminuras, 2003.

SILVA, J. O enigma da morte em Machado de Assis. 2006. Tese (Doutorado em Letras) Universidade Federal da Paraíba, João Pessoa, 2006.

SPINOZA, B. Oeuvres completes. Tradução de J. G. Prat. Deuxième série. Paris: Hachette, 1872.

. Oeuvres completes. Tradução de J. G. Prat. Première série. Paris: Hachette, 1873. . Spinoza opera. Im Augrag der Heidelberger Akademie der Wissenschaften herausgegeben von Carl Gebhardt. Heidelberg: C. Winter, 1925; 2. Auflage, 1972. 4 v. . Correspondencia. Tradução de A. Dominguez. Madrid: Alianza, 1988.

Recebido: 10/07/2016

Aceito: 16/06/2017 
OLIVEIRA, F. B. 